\title{
LITTLE TURKEY IN GREAT BRITAIN
}

İbrahim Sirkeci, Tuncay Bilecen, Yakup Çoştu, Saniye Dedeoğlu, M. Rauf Kesici, B. Dilara Seker, Fethiye Tilbe, K. Onur Unutulmaz (2016). Little Turkey in Great Britain, Transnational Press London, London, (ISBN: 978-1-910781-19-7), S. 181.

Mehmet Davut ÇOŞTU*

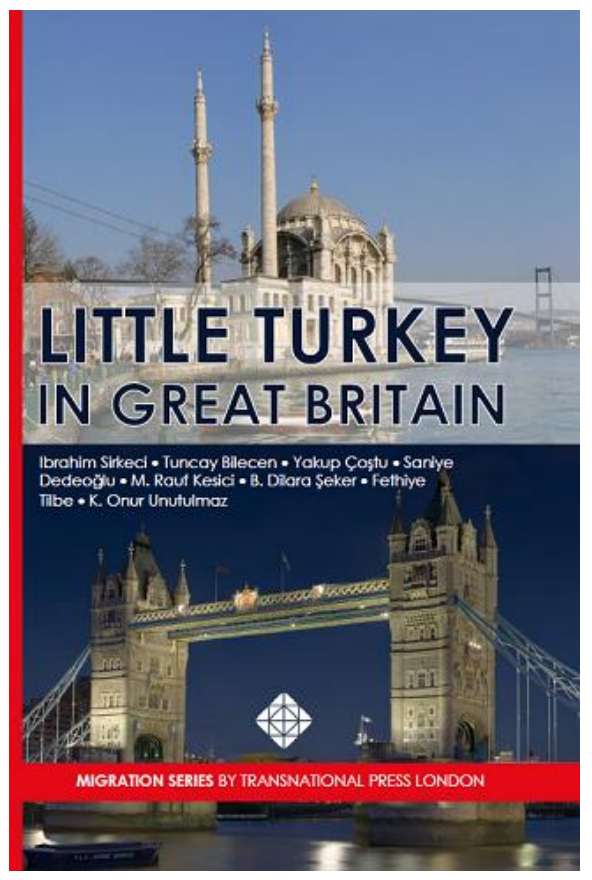

İngiltere'de Türkçe konuşan göçmenler hakkında bilgi vermesi açısından (bu alanda) önemli bir boşluğu dolduran "Little Turkey in Great Britain" adlı kitap, Birleşik Krallık'taki Türkçe Konuşan Toplulukların (TKT) ekonomik, sosyo-politik, kültürel ve dini yaşamlarına genel bir bakış sağlamak amaciyla farkl1 disiplinlerden gelen sekiz bilim adamı tarafından yazılmıştır. Her bölüm, alanının uzmanları tarafından ele alınmakta ve çoğu bölüm, 2010 ve 2015 yıllar1 arasında Londra'daki Türkçe Konuşan göçmenlerle yapılan araştırmalarda elde edilen etnografik verilere ve mülakatlara dayanmaktadır. Son zamanlarda yapilan araştırmalardan yararlanması sebebiyle güncel verileri bizlere sunmaktadır. Bölümler arasındaki üslup farkl11ıkları, bölümlerin farklı yazarlar tarafından yazıldığını göstermektedir. Ancak yazarların adları topluca verildiği için (yani yazarların isimleri her bir bölümün

\footnotetext{
* Doktora Öğrencisi, The Department of Politics, Philosophy and Religion, Lancaster University, Lancaster, United Kingdom. E-posta:davutcostu@hotmail.com
} 
içinde ayrı ayrı yazılmadığından dolayı) hangi bölümün hangi yazara ait olduğu bilinmemektedir. Bu kitap incelemesi, her bir bölümü ayr1 ayrı ele almayıp, aksine genel bakış açıları sunmakta ve bazı bölümlerde yer alan argümanlar aşağıda anlatacağımız biçimde değerlendirilmektedir.

Kitabın ilginç yönlerinden biri, Türkiye'deki son siyasi ayaklanmaların ve çatışmaların İngiltere'de Türkçe konuşan topluluklar üzerindeki etkisi konusunda doğru tahminlerde bulunmasıdır. Örneğin 2016'da yaşanan darbe girişiminin Türkiye'den İngiltere'ye göç akışını etkileyebileceğini ve bunun da İngiltere'ye gelen sığınmacı sayısında bir artışa neden olacağını kitap öngörmektedir. Bunun yanı sıra, istikrarlı bir hayat arayışı içinde olan Türk vatandaşlarının Ankara Anlaşması ve eğitim vizelerini bir geçit olarak kullanarak İngiltere'ye geleceğini dile getirmektedir. Kitapta yer aldığı üzere Ankara Anlaşmas1, yüksek eğitimli bireylerin resmi kanallar aracılığıyla İngiltere'ye taşınmasına izin vermektedir.

Kitabın giriş bölümü, TKT nüfusunun tartışmalı ve karmaşık oluşuna odaklaniyor. Eserde, İngiltere'de Türkçe konuşan göçmenler tarafından kurulmuş ve faaliyet gösteren sivil toplum örgütlerinin nüfus sayısı ile resmi kanallardan gelen nüfus sayıs1 arasında bir tutarsızlık olduğunu savunuyor. Kitabın yazarları, bu nüfus sayıları konusunda öne sürülen iddiaları, 2001 ve 2011 yıllarında İngiltere resmi kuruluşu tarafında yapılmış olan nüfus sayımını baz alarak değerlendirdiler. TKT kuruluşları, Birleşik Krallık'ta yaşayan TKT toplam nüfus sayısının resmi kaynaklarda yer alan rakamların çok üstünde olduğunu iddia etmişlerdir. İngiltere'de yaşayan Türkçe konuşan göçmenlerin toplam sayısı net değildir. Resmi son nüfus sayımı ve topluluk örgütlerinden alınan diğer bilgilerden yararlanarak, TKT nüfusun büyüklüğü 180.000 ile 250.000 arasında olduğu sonucuna ulaşılmaktadır. Kitaba göre, İngiltere'de faaliyette olup kar amacı gütmeyen bu vakıf ve kuruluşlar tarafından iddia edilen "yarım milyon Türk göçmen" rakamı gerçeği yansıtmamaktadır. Ayrıca, bu eser (nüfus sayısı açısından) 250.000'in üzerinde ileri sürülen her rakamın dayanaksız olduğunu, geçerliliğin olamayacağını ve güvenilirlikten yoksun olduğunu vurgulamışlardır. 
Yazarlar, TKT nüfus tahminlerini 250.000 'den daha az bir orana yerleştirmekte; İngiltere'deki TKT sivil organizasyonların Türkçe konuşan göçmen sayısını (olduğundan fazla görünmesini sağlamak için) yüksek gösterdiklerini ve dolayısıyla bu iddiaları gerçekçi bulmamaktadır. Diğer bir husus ise, Türkçe konuşan gurbetçiler gibi birçok göçmen grubuyla ile ilgili aynı tür tartışmalar yaşanmıştır. Kitapta da belirtildiği gibi, nüfus sayımı verileri TKT'nin Londra'daki en büyük ilk yirmi azınlık grubunda bile olmadığı baz alındığında, TKT'nin yarım milyon olduğu iddiası ne kadar doğru olabilir? Diğer taraftan bu konuyu ele alacak olursak, sadece İngiliz vatandaşı olup Türkçe konuşan göçmenler dikkate alındığında 200.000 rakamı gerçeği yansıtabilir.

Nitekim İngiltere'ye kolayca giriş çıkış yapan Bulgaristan pasaportlu Türkçe konuşan Türk işçilerinin sayısı da azımsanmayacak kadar çoktur. Bulgar Türkleri, kitabın dikkatinden kaçmış olup yeni oluşan bu TKT gurbetçileri kitapta yerini bulamamıştır. Bulgaristan'dan gelen Türkler İngiliz vatandaşı olmadığından ve İngiltere'de AB üyesi ülke vatandaşlığıyla birlikte çalıştıklarından bu işçiler resmi verilerde tam olarak yer almamaktadır. Özellikle, bu insanların sayısı İngiltere'deki küçük şehirlerde oldukça yüksektir. Kısacası, bu kitapta Bulgaristanlı Türk işçiler göz ard1 edilmiştir. Bunun nedeni, Bulgaristan'in 2007'den sonra AB üyesi olması ve bu süre zarfında İngiltere'de Bulgar Türklerinin yeni bir fenomen haline gelmesidir.

Öte yandan, aynı bölümde kitap başlı̆̆ seçiminde yaşanan zorluk da ele alınmıştır. Türkiye nüfusu Türk, Arap, Kürt, Laz, Çerkeş olmak üzere pekçok etnikten oluşmaktadır. Haliyle bu durum İngiltere'de yaşayan TK toplumunda da gözlemlenmektedir. Yazarlar "Büyük Britanya'da Küçük Türkiye" başlığını "Britanya'da Türkler" ismine neden tercih ettiklerini farklı argümanlar öne sürerek detaylı bir şekilde açıklamışlardır.

Kitabın yazarları Türkiye'den gelen göçmenlerin "Türkçe Konuşan Toplumlar" olarak tanımlanmasının, onlara "Türk" olarak atıfta bulunmaktan daha tarafsız olduğunu kabul etmişlerdir. "Türkçe Konuşan Toplumlar" tanımı, İngiltere'de yaşayan Kıbrıslı Türklerin yanı sıra Türkiye'den gelen Türkleri ve Kürtleri kapsamaktadır. Yazarlar ayrıca, Türkçenin tüm TKT göçmenlerinin tek ana dili olmasa 
da, göçmenlik açısından onları bir araya getiren önemli bir bağ olduğunu açıklamaktadır. Türkçe, bu topluluğu birbirine bağlayan en önemli faktör olduğu ortaya çıkmaktadır.

Topluluğun etnik kimliği ve nüfusunun büyüklüğü ile ilgili tartışmalı konular dışında, 3. bölümde TKT arasındaki siyasi görüşlere ve faaliyetlere genel bir bakış sunulmaktadır ve her bölümün kendi yazarı vardır, her biri farklı bir veri toplama tekniği ve çalışma yöntemi kullanmaktadır. Yazar bu bölümde, 2014-2015 yılları arasında Londra'daki TKT topluluğunun 60 üyesinden rastgele örneklemli yarı yapılandırılmış görüşmeler gerçekleştirmiştir. Veriler erkeklerin İngiliz siyasetiyle ilgilerinin kadınlardan daha fazla olduğunu gösteriyor. Kadınların siyasete ilgisiz olması, düşük İngilizce seviyeleri ve özellikle iş hayatında yer almamak gibi faktörlerden dolayı kamusal hayata sınırlı erişimlerinden kaynaklanmaktadır. Diğer önemli bir nokta da, özellikle Türkiye'den gelen TKT mensuplarının, göç meselesindeki tavrı ve olumlu politikasından dolayı çoğunlukla İşçi Partisi'ni desteklemeleridir. Ayrıca yazarlar, Kürtlerin siyasi partilere ve parti toplantılarına katılma konusunda politik olarak daha aktif olduklarını ileri sürüyorlar. Son seçimlerde, Kürtler ve Aleviler, Londra'da önceki yıllara kıyasla önemli yerel meclis sandalyeleri kazandılar. Ayrıca, kitapta bu bölüm, katılımcıların geniş bir yelpazedeki sosyal ve politik deneyimlere dair zengin bir tartışma sunmaktadır.

Kitap (4. bölüm) aynı zamanda (İngiltere'nin 1973'te katıldığı) Ankara Antlaşması'nın Türk vatandaşlarına verdiği "İngiltere'de ve AB'de çalışma ve oturum" hakkında geniş bir bölüm sunmaktadır. Son yirmi yılda, İngiltere'ye taşınmak isteyen Türk vatandaşları tarafindan beş binden fazla başvuru yapıldı. Türk vatandaşları bu resmi göç yolunu bu zamana kadar tercih ediyorlardı. Ancak bu antlaşma, Brexit'ten (2017) sonra geçersiz hale gelecektir. Genel olarak, bu bölüm, TKT üyelerinin Ankara Antlaşması kapsamında haklarını nasıl gördükleri ve kullandıklarıyla ilgili olarak literatürdeki bir boşluğu doldurmaktadır.

Kitabın diğer (6.) bölümünde, kadın ve cinsiyet konusuna dikkat çekilmektedir. Burada yazarlar, kadınların Birleşik Krallık'taki geniş aile işletmelerine farklı şekillerde katkılarda bulunduğunu iddia ediyor. Ailenin kadın üyeleri aile işletmelerinin ücretsiz işçilerdir. 
Çalışmaları resmi olarak kaydedilmediğinden, TKT kadın çalışanlarının sayısını tahmin etmek oldukça zordur. Buradaki önemli nokta, ailenin erkek üyeleri tarafından işletilen işletmelere katkıda bulunmasına rağmen kadınların katkısına dikkat edilememesidir.

Kitap (8. bölüm) ayrıca, göçmenlerin dini yerlerinin önemini de araştırmaktadır. Kültürel alışkanlıkların ve dini kimliklerin korunması sürecinde dini örgütler ve vakıfların önemli bir rol oynadığı kitabın 8. bölümünde ele alınmıştır. Bu sivil kuruluşların dini hizmetlerinin yanı sıra, sahip oldukları binaların birden fazla işlevleri vardır. Bu binalar sadece dini bir alan olmayıp, kültürel, sosyal, eğitici ve hatta politik aktiviteleri organize eden bir alan haline gelmiştir. $\mathrm{Bu}$ bölümde ele alınan husus, dini örgütlerin Türkçe konuşan göçmenlerin yoğun olduğu mahallelerde faaliyet gösterdiği ve binalarını toplum hizmetine sunan bir nevi kültür merkezi haline gelmeleridir.

Sonuç olarak, bu kitap İngiltere'de yoğun olarak yaşayan Türkleri, Kürtleri ve Kıbrıslı Türkleri araştıran ve inceleyen akademisyenler için kayda değer güncel veriler sunmaktadır. Bu kitap, İngiltere'de hâlâ faaliyetlerine devam eden, camiden futbol kulüplerine kadar birçok alanı kapsayan, TKT toplumlarını araştırmak ve bu konuda bilgi edinmek isteyen okuyuculara tanitım mahiyetinde bilgiler sunmaktadır. $\mathrm{Bu}$ eserin Avrupa ve İngiltere'de yaşayan Türkçe konuşan göçmenler konusunda gelecekte çalışma yapmak isteyen araştırmacılar için temel ve güncel bir kaynak olacağına şüphe yoktur. 
